\title{
LOBAR ALVEOLAR GAS CONCENTRATIONS: EFFECT OF BODY POSITION ${ }^{1}$
}

\author{
By C. J. MARTIN, FRANK CLINE, JR., AND HELEN MARSHALL
}

(From the Department of Physiology, Firland Sanatorium and the Department of Medicine, University of Washington, Seattle, Washington)

(Submitted for publication November 3, 1952; accepted March 11, 1953)

The concept that the composition of alveolar air may vary in space and time has occupied the attention of many investigators. Changes in ventilation and/or perfusion may alter the alveolar gas composition in normal lungs. The first published work on unequal ventilation in the lungs is usually attributed to Grehant in 1864 . Recent studies (1-5) have involved measuring the concentration of a given gas in the expired air sampled at mouth level. Variation in gas concentration in the alveolar portion of expiration has been used as evidence for unequal intrapulmonary gas distribution. The probability of unequal pulmonary blood flow has been discussed (6-8).

The purpose of the present study is to (1) measure simultaneously the end-expiratory alveolar gas concentration within the lobar bronchus of the right upper lobe and the right lower lobe (or segments of the same), and (2) determine the effect of body position upon these concentrations.

\section{METHODS}

Subjects were normal volunteers or patients with normal lungs. All were ambulant and between the ages of 21 and 35 years. Distribution between the sexes was approximately equal. Under basal conditions, the subject was given a barbiturate, $0.1 \mathrm{gm}$. by mouth, and all but three subjects were given atropine sulphate, 0.41 mgm., subcutaneously thirty to forty minutes before the experiment. The larynx and pharynx were anesthetized with cocaine ( 5 per cent) in epinephrine $(1: 4000)$ as for routine bronchospirometry. A number 16 urethral catheter, from which the distal $4 \mathrm{~cm}$. had been amputated, was introduced through the mouth into the trachea. Two radio-opaque poly-vinyl catheters $(2 \mathrm{~mm}$. OD, $1 \mathrm{~mm}$. ID, $70 \mathrm{~cm}$. long) were introduced through this catheter. A wire guide filling the lumen of each poly-vinyl catheter provided better control of the distal tip. The right upper lobe catheter had an 80 degree curvature in its distal portion, beginning within $2 \mathrm{~cm}$. of the tip. After the

1 This investigation was supported in part by a research grant from the National Institutes of Health, Public Health Service, in part by a grant from the Firland Health Grads. small catheters were in the trachea, the urethral catheter was removed and the subject was placed on the fluoroscopic table. Under direct fluoroscopic vision, each catheter was guided into the selected lobar bronchus and the wire guide removed. After the subject was in position for approximately 15 to 20 minutes the first samples were taken. The subject was in each subsequent position 5 to 20 minutes before further samples were taken. Simultaneous samples from the right upper and right lower lobe bronchi were taken in pre-evacuated mercury sampling tubes (9), so constructed that the dead space of the catheter and tube could be cleared before the sample was taken. Gas was analyzed in duplicate in a Scholander $0.5 \mathrm{cc}$. gas analyzer. Samples were taken in the last one-third of expiration or in the expiratory pause. If either of two observers questioned the timing, the samples were discarded. The volume of each sample seldom exceeded $6 \mathrm{cc}$.

Samples were taken with the subject in the horizontal position, in 10 to 30 degrees Trendelenburg and upright. A motor driven fluoroscopic tilt table was used to change position. Sequence of positions used was varied. At the termination of the procedure approximately $1 \mathrm{cc}$. of contrast mixture was instilled through each catheter and roentgenograms were taken to localize the tip of the catheter.

\section{RESULTS}

Results in 13 of 21 subjects are presented in Table I. We were unable to catheterize the right upper lobe orifice in five subjects. Two others experienced syncope when upright and are not included. One male subject had an abnormal respiratory rhythm with an inspiratory pause. This was, in effect, a breath-holding experiment which is being studied further.

Eighteen simultaneous right upper and right lower lobe gas samples were obtained from 11 upright subjects (Table I). In each instance the end-expiratory oxygen concentration from the right upper lobe was higher than that from the right lower lobe. The mean oxygen difference was 2.136 Vol. per cent which is statistically significant by the paired samples method $(\mathrm{P}<.001)$. Endexpiratory carbon dioxide concentration was higher from the right lower than the right upper lobe by 
TABLE I

Simultaneous upper and lower lobe alveolar air values in upright, horizontal and Trendelenburg positions

\begin{tabular}{|c|c|c|c|c|c|c|c|c|c|c|c|c|c|c|}
\hline \multirow{3}{*}{ Subject } & \multirow{3}{*}{$\begin{array}{l}\text { Barom- } \\
\text { eter. }\end{array}$} & \multirow{3}{*}{ Catheter } & \multicolumn{4}{|c|}{ Upright } & \multicolumn{4}{|c|}{ Horizontal } & \multicolumn{4}{|c|}{ Trendelenburg } \\
\hline & & & \multicolumn{2}{|c|}{ Volume $\%$} & \multirow{2}{*}{ R.Q.* } & \multirow{2}{*}{$\begin{array}{l}\text { Minutes } \\
\text { upright } \\
\text { before } \\
\text { sample }\end{array}$} & \multicolumn{2}{|c|}{ Volume $\%$} & \multirow{2}{*}{ R.Q.* } & \multirow{2}{*}{$\begin{array}{l}\text { Minutes } \\
\text { supine } \\
\text { before } \\
\text { sample }\end{array}$} & \multicolumn{2}{|c|}{ Volume $\%$} & \multirow{2}{*}{ R.Q.* } & \multirow{2}{*}{$\begin{array}{l}\text { Minutes in } \\
\text { Trendel. } \\
\text { position } \\
\text { before } \\
\text { sample }\end{array}$} \\
\hline & & & $\mathrm{O}_{2}$ & $\mathrm{CO}_{2}$ & & & $\mathrm{O}_{2}$ & $\mathrm{CO}_{2}$ & & & $\mathrm{O}_{2}$ & $\mathrm{CO}_{2}$ & & \\
\hline J. K. & $\begin{array}{l}m m . \mathrm{Hg} \\
729.5\end{array}$ & $\begin{array}{l}\text { RUL } \\
\text { RLL }\end{array}$ & $\begin{array}{l}13.00 \\
10.74\end{array}$ & $\begin{array}{l}4.72 \\
5.10\end{array}$ & $\begin{array}{l}0.54 \\
0.44\end{array}$ & 3 & $\begin{array}{l}12.36 \\
14.98\end{array}$ & $\begin{array}{l}4.43 \\
4.23\end{array}$ & $\begin{array}{l}0.46 \\
0.66\end{array}$ & 15 & $\dagger$ & & & \\
\hline B. E. & 741.4 & $\begin{array}{l}\text { RUL } \\
\text { RLL }\end{array}$ & $\begin{array}{l}18.74 \\
17.79\end{array}$ & $\begin{array}{l}1.77 \\
2.30\end{array}$ & $\begin{array}{l}0.78 \\
0.69\end{array}$ & 7.0 & $\begin{array}{l}17.69 \\
18.37\end{array}$ & $\begin{array}{l}3.08 \\
2.80\end{array}$ & $\begin{array}{l}0.95 \\
1.14\end{array}$ & 10 & $\begin{array}{l}16.18 \\
18.08\end{array}$ & $\begin{array}{l}3.60 \\
3.06\end{array}$ & $\begin{array}{l}0.72 \\
1.11\end{array}$ & 5 \\
\hline J. D. & 738.9 & $\begin{array}{l}\text { RUL } \\
\text { RLL }\end{array}$ & $\begin{array}{c}13.87 \\
\ddagger\end{array}$ & 5.10 & 0.68 & 30 & $\begin{array}{l}15.61 \\
15.64\end{array}$ & $\begin{array}{l}4.60 \\
4.73\end{array}$ & $\begin{array}{l}0.84 \\
0.88\end{array}$ & 15 & $\begin{array}{l}14.19 \\
15.37\end{array}$ & $\begin{array}{l}5.21 \\
4.64\end{array}$ & $\begin{array}{l}0.73 \\
0.80\end{array}$ & 5 \\
\hline S. C. & 730.0 & $\begin{array}{l}\text { RUL } \\
\text { RLL }\end{array}$ & $\begin{array}{l}18.08 \\
16.86\end{array}$ & $\begin{array}{l}2.35 \\
3.11\end{array}$ & $\begin{array}{l}0.80 \\
0.73\end{array}$ & 16.0 & $\begin{array}{l}14.43 \\
14.75\end{array}$ & $\begin{array}{l}4.87 \\
4.66\end{array}$ & $\begin{array}{l}0.71 \\
0.71\end{array}$ & 15 & $\begin{array}{l}16.16 \\
16.17\end{array}$ & $\begin{array}{l}4.01 \\
4.19\end{array}$ & $\begin{array}{l}0.81 \\
0.86\end{array}$ & 10 \\
\hline E. S. & 768.7 & $\begin{array}{l}\text { RUL } \\
\text { RLL } \\
\text { RUL } \\
\text { RLL }\end{array}$ & $\begin{array}{l}13.63 \\
11.28 \\
13.88 \\
10.68\end{array}$ & $\begin{array}{l}5.13 \\
5.50 \\
5.31 \\
6.13\end{array}$ & $\begin{array}{l}0.65 \\
0.51 \\
0.71 \\
0.54\end{array}$ & $\begin{array}{r}5 \\
14\end{array}$ & $\begin{array}{r}9.26 \\
11.52\end{array}$ & $\begin{array}{l}5.94 \\
5.69\end{array}$ & $\begin{array}{l}0.45 \\
0.55\end{array}$ & 11 & $\begin{array}{r}10.90 \\
9.72\end{array}$ & $\begin{array}{l}5.84 \\
5.95\end{array}$ & $\begin{array}{l}0.53 \\
0.47\end{array}$ & 6 \\
\hline B. W. & 744.57 & $\begin{array}{l}\text { RUL } \\
\text { RLL } \\
\text { RUL } \\
\text { RLL }\end{array}$ & $\begin{array}{l}14.42 \\
12.56 \\
14.54 \\
12.58\end{array}$ & $\begin{array}{l}4.85 \\
5.31 \\
4.87 \\
5.43\end{array}$ & $\begin{array}{l}0.70 \\
0.58 \\
0.72 \\
0.60\end{array}$ & $\begin{array}{l}15 \\
18\end{array}$ & $\begin{array}{l}13.02 \\
13.20\end{array}$ & $\begin{array}{l}5.36 \\
5.25\end{array}$ & $\begin{array}{l}0.63 \\
0.63\end{array}$ & 15 & $\begin{array}{l}13.09 \\
12.23\end{array}$ & $\begin{array}{l}5.53 \\
5.55\end{array}$ & $\begin{array}{l}0.66 \\
0.58\end{array}$ & 12 \\
\hline W. R. & 745.5 & $\begin{array}{l}\text { RUL } \\
\text { RLL } \\
\text { RUL } \\
\text { RLL }\end{array}$ & $\begin{array}{l}14.97 \\
12.45 \\
17.05 \\
14.48\end{array}$ & $\begin{array}{l}4.24 \\
4.95 \\
3.42 \\
4.38\end{array}$ & $\begin{array}{l}0.67 \\
0.53 \\
0.86 \\
0.63\end{array}$ & $\begin{array}{r}7 \\
18\end{array}$ & $\begin{array}{l}14.35 \\
14.86\end{array}$ & $\begin{array}{l}4.37 \\
4.40\end{array}$ & $\begin{array}{l}0.61 \\
0.68\end{array}$ & 14 & $\begin{array}{l}13.87 \\
14.93\end{array}$ & $\begin{array}{l}4.67 \\
4.26\end{array}$ & $\begin{array}{l}0.61 \\
0.66\end{array}$ & 5 \\
\hline F. $O$. & 746.24 & $\begin{array}{l}\text { RUL } \\
\text { RLL }\end{array}$ & $\begin{array}{c}15.87 \\
\S\end{array}$ & 4.37 & 0.84 & 14 & $\begin{array}{l}13.18 \\
14.45\end{array}$ & $\begin{array}{l}5.34 \\
4.73\end{array}$ & $\begin{array}{l}0.64 \\
0.68\end{array}$ & 9 & $\begin{array}{c}13.34 \\
\S\end{array}$ & 5.40 & 0.66 & 10 \\
\hline D. H. & 717.84 & $\begin{array}{l}\text { RUL } \\
\text { RLL } \\
\text { RUL } \\
\text { RLL }\end{array}$ & $\begin{array}{l}18.12 \\
15.81\end{array}$ & $\begin{array}{l}2.90 \\
3.74\end{array}$ & $\begin{array}{l}1.05 \\
0.69\end{array}$ & 4 & $\begin{array}{l}15.12 \\
17.76 \\
16.42 \\
17.22\end{array}$ & $\begin{array}{l}4.08 \\
2.83 \\
3.79 \\
1.52\end{array}$ & $\begin{array}{l}0.65 \\
0.88 \\
0.81 \\
0.36\end{array}$ & $\begin{array}{l}11 \\
12\end{array}$ & $\begin{array}{l}15.80 \\
17.27\end{array}$ & $\begin{array}{l}3.68 \\
3.42\end{array}$ & $\begin{array}{l}0.67 \\
0.93\end{array}$ & 6 \\
\hline S. B. & 756.14 & $\begin{array}{l}\text { RUL } \\
\text { RLL } \\
\text { RUL } \\
\text { RLL }\end{array}$ & $\begin{array}{l}15.14 \\
13.71 \\
15.62 \\
13.56\end{array}$ & $\begin{array}{l}4.99 \\
5.16 \\
4.88 \\
5.16\end{array}$ & $\begin{array}{l}0.84 \\
0.67 \\
0.91 \\
0.65\end{array}$ & $\begin{array}{l}11 \\
13\end{array}$ & $\begin{array}{l}13.52 \\
13.70\end{array}$ & $\begin{array}{l}5.38 \\
5.14\end{array}$ & $\begin{array}{l}0.68 \\
0.66\end{array}$ & 6 & $\dagger$ & & & \\
\hline F. P. & 752.63 & $\begin{array}{l}\text { RUL } \\
\text { RLL } \\
\text { RUL } \\
\text { RLL }\end{array}$ & $\begin{array}{l}17.03 \\
14.53 \\
17.58 \\
14.83\end{array}$ & $\begin{array}{l}3.56 \\
4.29 \\
3.29 \\
4.18\end{array}$ & $\begin{array}{l}0.90 \\
0.62 \\
0.99 \\
0.64\end{array}$ & $\begin{array}{r}8 \\
18\end{array}$ & $\begin{array}{l}11.03 \\
15.34 \\
12.99 \\
15.45\end{array}$ & $\begin{array}{l}5.32 \\
4.44 \\
4.86 \\
3.75\end{array}$ & $\begin{array}{l}0.48 \\
0.76 \\
0.56 \\
0.64\end{array}$ & $\begin{array}{l}12 \\
31\end{array}$ & $\dagger$ & & & \\
\hline E. N. & 758.21 & $\begin{array}{l}\text { RUL } \\
\text { RLL } \\
\text { RUL } \\
\text { RLL }\end{array}$ & $\begin{array}{l}14.73 \\
12.70 \\
14.97 \\
12.71\end{array}$ & $\begin{array}{l}3.81 \\
4.25 \\
3.98 \\
4.55\end{array}$ & $\begin{array}{l}0.56 \\
0.46 \\
0.62 \\
0.50\end{array}$ & $\begin{array}{l}5 \\
7\end{array}$ & $\begin{array}{l}15.46 \\
16.06 \\
14.31 \\
15.45\end{array}$ & $\begin{array}{l}4.83 \\
4.66 \\
4.31 \\
4.16\end{array}$ & $\begin{array}{l}0.86 \\
0.95 \\
0.60 \\
0.72\end{array}$ & $\begin{array}{l}10 \\
13\end{array}$ & $\begin{array}{l}10.20 \\
13.34\end{array}$ & $\begin{array}{l}4.77 \\
4.48\end{array}$ & $\begin{array}{l}0.39 \\
0.54\end{array}$ & 15 \\
\hline H. R. & 748.3 & $\begin{array}{l}\text { RUL } \\
\text { RLL } \\
\text { RUL } \\
\text { RLL }\end{array}$ & $\begin{array}{l}18.20 \\
16.17 \\
17.55 \\
15.35\end{array}$ & $\begin{array}{l}1.95 \\
3.13 \\
3.18 \\
3.95\end{array}$ & $\begin{array}{l}0.67 \\
0.61 \\
0.94 \\
0.66\end{array}$ & $\begin{array}{r}6 \\
24\end{array}$ & $\begin{array}{l}16.50 \\
15.93 \\
16.37 \\
15.74\end{array}$ & $\begin{array}{l}4.09 \\
4.36 \\
4.06 \\
4.29\end{array}$ & $\begin{array}{l}0.91 \\
0.85 \\
0.87 \\
0.80\end{array}$ & $\begin{array}{r}5 \\
19\end{array}$ & $\dagger$ & & & \\
\hline R. S.\| & 756.0 & $\begin{array}{l}\text { LUL } \\
\text { LLL }\end{array}$ & $\begin{array}{l}15.81 \\
14.23\end{array}$ & $\begin{array}{l}4.39 \\
5.00\end{array}$ & $\begin{array}{l}0.83 \\
0.70\end{array}$ & 7 & $\begin{array}{l}13.58 \\
14.82\end{array}$ & $\begin{array}{l}5.80 \\
5.53\end{array}$ & $\begin{array}{l}0.75 \\
0.89\end{array}$ & 23 & $\begin{array}{l}11.52 \\
14.64\end{array}$ & $\begin{array}{l}6.11 \\
5.05\end{array}$ & $\begin{array}{l}0.60 \\
0.77\end{array}$ & 6 \\
\hline
\end{tabular}

* Correction formula from Handbook of Respiratory Data in Aviation.

† Samples not taken in this position.

$\ddagger$ Catheter plugged, no sample obtained.

Sampling tubes broken.

II All samples from the left, see text. 
a mean of $0.634 \mathrm{Vol}$. per cent. This is highly significant $(\mathrm{P}<.001)$. In each of the paired samples the respiratory exchange ratio was higher in the right upper lobe bronchus. The mean difference in R.Q. (correction formula for alveolar air from the "Handbook of Respiratory Data in Aviation") is $0.176(\mathrm{P}<.001)$.

In the supine position (Table I) there were 17 simultaneous upper and lower lobe determinations on 13 subjects. In each instance, excepting one subject (H. R.), the end-expiratory oxygen concentration was higher in the right lower lobe than in the right upper lobe. The mean difference was 1.106 Vol. per cent and is significant $(\mathrm{P}<.005)$. The end-expiratory carbon dioxide concentration was higher in the right upper lobe than in the right lower lobe by a mean of 0.416 Vol. per cent $(P=0.02)$. The respiratory exchange ratio was lower in the upper lobe bronchus by a mean of 0.049 (not statistically significant).

There was no statistically significant difference between right upper lobe and right lower lobe end-expiratory gas concentrations in eight subjects in Trendelenburg position (Table I). Endexpiratory oxygen concentration in the right lower lobe bronchus was higher than in the right upper lobe bronchus by a mean of $0.84 \mathrm{Vol}$. per cent $(\mathrm{P}<0.10)$. End-expiratory carbon dioxide was higher in the lower lobe bronchus by a mean of 0.22 Vol. per cent. The R.Q. was higher in the right lower lobe bronchus by a mean of 0.104 .

Left upper lobe and left lower lobe end-expiratory gas concentrations have been determined in one subject (Table I). This man had moderately advanced pulmonary tuberculosis on the right, with no evidence of disease in the left lung. These values are similar to those described above for the right lung. These results are not included in the statistical study.

One subject (H. R.) when supine showed higher end-expiratory oxygen values in the upper lobe than in the lower lobe. Carbon dioxide and R.Q. values were similarly opposite to those of other subjects in this position. This study was repeated after a two month interval at which time similar differences were obtained. We have no explanation for this deviation from the usual pattern in an apparently healthy woman.

While precautions were taken to prevent contamination, these may have failed in some cases.
Low carbon dioxide tensions may indicate inspiratory contamination or hyperventilation. Hyperventilation was noted in some cases. However, in all cases the respiratory exchange ratio was higher in the upper lobe in the upright subject, an indication of a real difference between the two lobes in their ventilation-perfusion ratios.

Independent statistical analysis by Dr. Paul T. Bruyere, National Institutes of Health, agrees with the preceding statistical values. Dr. Bruyere used the analysis of variance criteria and contributed further information' on the above studies. "Comparisons of successive determinations in the upright position made on seven subjects reveal no significant trends. Total change between determinations, rate of change per minute, and rate of change related to number of minutes upright before the first determination were all studied. Oxygen and carbon dioxide concentrations and respiratory quotient all showed small average increases, but the changes varied greatly from one subject to another. No significant relationship could be established between any one of the three measures of respiration (oxygen, carbon dioxide, and respiratory quotient) and any of the accessory factors recorded; pulse, respiration, catheter position, medication." (The "catheter position" in Dr. Bruyere's analysis refers to the position within the lobe and not to differences between lobes which did show statistical difference.)

\section{DISCUSSION}

Others have obtained samples of alveolar air from the bronchi of human subjects. Loewy and Schrötter (10) (1905) used a catheter with an inflatable rubber cuff at its distal end, obtaining alveolar air in equilibrium with mixed venous blood. There was no ventilation of the lung area sampled. Birath (11) used small catheters which permitted lung ventilation. Samples were obtained from the trachea and lower lobe bronchi of tuberculous patients with pneumothorax. We are now studying the effect of collapse procedures on alveolar air concentrations.

By directly measuring end-expiratory alveolar air from the lobar bronchi, we have shown regional differences to exist. These lobar differences can be markedly changed by body position. When each subject was upright, the carbon dioxide con- 
centration was lower, the oxygen concentration was higher, and the R.Q. was higher in the right upper lobe than in the right lower lobe. These relationships were reversed in most subjects in the supine position. Whether this pattern is a result of ventilation and/or perfusion changes cannot be stated.

"Spot" sampling of alveolar air has been criticized as being unable to describe a value which varies throughout a wide range. The numerical values given for lobar alveolar gas concentrations are not absolute but we believe simultaneous sampling from upper and lower lobe bronchi provide comparable values for one period (time) in the expiratory cycle. Our results show the effect of body position upon comparable samples from different lobes (space). Rapid gas analyzers may solve this problem.

Haldane, Meakins and Priestley (12), studying shallow breathing, felt that the recumbent position resulted in more unequal ventilation than the upright position. Rauwerda (5) shared this view. If unequal ventilation is the cause of the lobar differences in R.Q. observed in this study, we cannot agree with this conclusion. We found greater differences in alveolar gas concentrations between lobes in the upright than in the supine subject. Only by assuming a change in pulmonary perfusion can these findings be consistent with more even ventilation in the upright subject.

Roelsen (6) believed unequal pulmonary perfusion as well as unequal ventilation to be present in normal man. Rahn (7) and Riley and Cournand (8) assume the existence of unequal pulmonary blood flow as well as unequal pulmonary ventilation. Thus "mean" or "ideal" alveolar gas tensions, as defined by these authors, provide a value compatible with the quantitative aspects of gas exchange. Rahn has shown that "mean" alveolar gas tensions and end-tidal air tensions measured at mouth level are similar in normal man. End-tidal gas values from lobar bronchi suggest the magnitude of variation in ventilation-perfusion relationships which is being described by a single value.

Dock's (13) theory on the apical localization of adult pulmonary tuberculosis has been confirmed in one respect. He believed that when man was upright, the pulmonary blood flow was de- creased in the upper portion of the lung as a result of low pulmonary arterial pressure. Hence there would be little gas exchange between the alveoli and blood in the apex of the lung and high oxygen tensions would exist. However, the work of Scott, Hanlon, and Olson (14) in monkeys suggests that pulmonary blood flow itself is not the major factor in this apical localization. Their monkeys with a systemic to pulmonary arterial anastomosis showed extensive caseous lesions on the side of the anastomosis. Similarly on the side of a ligated pulmonary artery the same type of lesion occurred. The opposite lung showed the miliary type of tuberculosis seen in control animals. Rich and Follis (15) have shown that the oxygen content of inspired air markedly influences tuberculous lesions in infected rabbits and guinea pigs. As the oxygen concentration was lowered below 12 Vol. per cent progressive inhibition of tuberculous lesions occurred. The experiments of Scott, Hanlon, and Olson suggest that the caseous changes observed in operated monkeys are related to high oxygen tensions in the arterialized pulmonary tissue. In the present study we have shown that high oxygen tensions exist in the apex of the lung in the upright man. Differences such as we have described in the upper and lower lobe oxygen concentrations may favor the growth of the bacillus in the apex when man is upright. Similarly when the subject is on bed-rest with lowered oxygen tensions in the upper lobe, the bacillus is at a disadvantage for its oxidative needs.

\section{CONCLUSION}

1. Lobar differences in alveolar gas concentrations do exist.

2. Body position affects lobar gas concentrations in the following manner :

a) When upright, end-expiratory oxygen is higher and carbon dioxide is lower in the right upper lobe than in the right lower lobe. The R.Q. is higher in the right upper lobe.

b) When supine, the end-expiratory oxygen is higher and the carbon dioxide concentration is lower in the right lower lobe than in the right upper lobe. The R.Q. shows no significant difference between the two lobes. Apparently ventilation-perfusion relation- 
ships are not as greatly altered in this position as in the upright position.

c) In the Trendelenburg position there is no statistically significant difference between the upper and lower lobe gas concentrations.

3. A factor in the apical localization of adult pulmonary tuberculosis may be the higher oxygen tension in the upper lobe in the upright man.

\section{ACKNOWLEDGMENT}

We are indebted to Florence Best and Sergey Politoff for technical assistance and to the many volunteers who made this study possible.

\section{REFERENCES}

1. Sonne, C., Inequality of ventilation of different parts of the lung as a source of error in respiratoryphysiological experiments. Skandinav. Arch. f. Physiol., 1936, 75, 127.

2. Roelsen, E., Fractional analysis of alveolar air after inspiration of hydrogen as a method for determination of the distribution of inspired air in the lungs. Examination of normal persons and of patients suffering from bronchial asthma and pulmonary emphysema. Acta med. Scandinav., 1938, 95, 452.

3. Cournand, A., Baldwin, E. DeF., Darling, R. C., and Richards, D. W., Jr., Studies on intra-pulmonary mixture of gases. IV. Significance of pulmonary emptying rate and a simplified open circuit measurement of residual air. J. Clin. Invest., 1941, 20, 681.

4. Fowler, W. S., Lung function studies. III. Uneven pulmonary ventilation in normal subjects and in patients with pulmonary disease. J. Applied Physiol., 1949, 2, 283.
5. Rauwerda, P. E., Unequal ventilation of different parts of the lung and the determination of cardiac output, Dissertation, Groningen Univ., Netherlands, 1946.

6. Roelsen, E., The composition of the alveolar air investigated by fractional sampling. Comparative investigations on normal persons and patients with bronchial asthma and pulmonary emphysema. Acta med. Scandinav., 1939, 98, 141.

7. Rahn, H., A concept of mean alveolar air and the ventilation-blood flow relationships during pulmonary gas exchange. Am. J. Physiol., 1949, 158, 21.

8. Riley, R. L., and Cournand, A., 'Ideal' alveolar air and the analysis of ventilation-perfusion relationships in the lungs. J. Applied Physiol., 1949, 1, 825.

9. Forssander, C. A., Vacuum sampling tube for respiratory gases. J. Lab. \& Clin. Med., 1949, 34, 881.

10. Loewy, A., and Schrötter, H. v., Untersuchungen über die Blutcirculation beim Menschen. Ztschr. f. exper. Path. u. Therap., 1905, 1, 197.

11. Birath, Gösta, Simultaneous samples of alveolar air from each lung and parts thereof. Am. Rev. Tuberc., 1947, 55, 444.

12. Haldane, J. S., Meakins, J. S., and Priestley, J. G., The effects of shallow breathing. J. Physiol., 1919, 52, 433.

13. Dock, W., Apical localization of phthisis. Its significance in treatment by prolonged rest in bed. Am. Rev. Tuberc., 1946, 53, 297.

14. Scott, H. W., Jr., Hanlon, C. R., and Olson, B. J., The effects of experimental alteration of the pulmonary arterial circulation on tuberculosis in monkeys. Bull. Johns Hopkins Hosp., 1951, 88, 376.

15. Rich, A. R., and Follis, R. H., Jr., The effect of low oxygen tension upon the development of experimental tuberculosis. Bull. Johns Hopkins Hosp., 1942, 71, 345.

\section{SPECIAL NOTICE TO SUBSCRIBERS}

Post Offices will no longer forward the Journal when you move.

Please notify The Journal of Clinical Investigation, Business Office, 622 West 168th Street, New York 32, N. Y. at once when you have a change of address, and do not omit the zone number if there is one. 